IZA DP No. 5444

Wage Inequality of U.S. Truck Drivers

Kristen Monaco

Steffen Habermalz

January 2011 


\title{
Wage Inequality of U.S. Truck Drivers
}

\author{
Kristen Monaco \\ California State University, Long Beach \\ Steffen Habermalz \\ Northwestern University \\ and IZA
Discussion Paper No. 5444
January 2011 \\ IZA \\ P.O. Box 7240 \\ 53072 Bonn \\ Germany \\ Phone: +49-228-3894-0 \\ Fax: +49-228-3894-180 \\ E-mail: iza@iza.org
}

Any opinions expressed here are those of the author(s) and not those of IZA. Research published in this series may include views on policy, but the institute itself takes no institutional policy positions.

The Institute for the Study of Labor (IZA) in Bonn is a local and virtual international research center and a place of communication between science, politics and business. IZA is an independent nonprofit organization supported by Deutsche Post Foundation. The center is associated with the University of Bonn and offers a stimulating research environment through its international network, workshops and conferences, data service, project support, research visits and doctoral program. IZA engages in (i) original and internationally competitive research in all fields of labor economics, (ii) development of policy concepts, and (iii) dissemination of research results and concepts to the interested public.

IZA Discussion Papers often represent preliminary work and are circulated to encourage discussion. Citation of such a paper should account for its provisional character. A revised version may be available directly from the author. 
IZA Discussion Paper No. 5444

January 2011

\section{ABSTRACT}

\section{Wage Inequality of U.S. Truck Drivers}

Using CPS data for the period 1979-2009, the wage dispersion of truck drivers (and subsets of the truck driving sample) is compared to the trends in wage dispersion of males economywide. We find that truckers' wages experienced a decrease in inequality post-deregulation, as expected given the literature on regulation's impact on the labor market. We also find that the wage dispersion for truckers is markedly different from males economy-wide, providing evidence that the wage distribution of truck drivers has been dominated by the changing structure of the occupation post-deregulation and largely immune to the factors that increased inequality for the aggregate labor market.

JEL Classification: J31, L92

Keywords: $\quad$ wage differentials, wage inequality, trucking

Corresponding author:

Steffen Habermalz

Department of Economics

Northwestern University

2001 Sheridan Road

Evanston, Illinois 60208

USA

E-mail: s-habermalz@northwestern.edu 


\section{Introduction}

There has been a well-documented change in the U.S. wage structure during the last 30 years. Early research on this topic focused on a wide variety of possible causes of wage inequality, such as decreases in union coverage, international trade, and immigration (for a summary see Levy and Murnane 1992). In general, the likely causes can be categorized into market factors (shifts in labor supply and/or demand) and institutional factors (changes in the minimum wage). While some research shows that institutional factors and changes in labor supply played a role in changing the wage structure (Card and DiNardo 2002 and Goldin and Katz 2008), other research concludes that any complete explanation of the increase in wage inequality should account for an increase in the relative demand for skilled versus unskilled labor (Autor et al. 2008).The main explanation forwarded in this literature is skill-biased technological change (SBTC). While early research typically portrayed SBTC as having a monotonic effect on relative skill demand (Juhn, Murphy, and Pierce 1993, Autor et al. 1998 and Katz et al. 1999), recent work by Autor et al. (2003) and Autor and Dorn (2008) provides evidence that the impact of SBTC differs by occupation, based on the set of tasks a worker performs. Moretti (2008) also shows that the demand shocks that lead to increases in inequality seem to be locally concentrated in select urban areas.

Autor et al. (2003) and Autor and Dorn (2008) both model SBTC affecting high-skilled vs. low-skilled workers through the tasks they perform. Both papers take as a starting point the fact that the price of computer equipment has fallen tremendously over the last 30 years. The former paper enumerates two tasks, abstract and routine, and assumes that computers are perfect substitutes for routine tasks. Autor and Dorn (2008) extend this model and include manual tasks in their model that cannot be substituted with computers. In both papers the drop in the price of 
computer equipment and the ensuing substitution of computers for performing routine tasks lead to lower wages and employment of those (low-skilled) workers that compete with computers. However, these models posit an ambiguous relationship between computerization and the wages of workers in occupations for which computers cannot be easily substituted, as the relative magnitude of the shifts in labor supply and demand are unknown. Therefore, one must gain insight empirically. This paper aims to fill part of this void by investigating the evolution of wage inequality for U.S. truck drivers. Trucking services have arguably not experienced a vast amount of technological change and, so far, truck driving cannot be performed by a computer. Technological change in the trucking sector has largely been confined to trucking firms’ adoption of technologies to monitor fleets, facilitate communication with drivers, and improve logistics (Baker and Hubbard 2004). Both technologies would be expected to compress wages due to lower skill requirements. The job of driving the truck itself has not undergone vast changes.

Unrelated to SBTC, documenting the development of wage inequality for truck drivers is interesting in its own right because, like other modes of transportation, the trucking sector underwent an episode of considerable institutional change during the period that also marks the beginning of the economy-wide change in wage inequality. Beginning in the 1970s interstate trucking was deregulated, leading to an enormous change in industry structure and an accompanying decrease in union density.

In this paper we analyze the change in the wage inequality for U.S. truck drivers over the period 1979-2009. Using Current Population Survey data, we compare and contrast the economy-wide changes in wage inequality with those of truck drivers. We also examine the effect of institutional factors, namely the real value of the federal minimum wage and 
unionization, on wage inequality. We find that the evolution of wage inequality for truck drivers is quite different from the rest of the economy and that, over the period in question, truck driver wage inequality stabilized and, in some cases, actually decreased. We also find that the real value of the minimum wage and the degree of union coverage can only explain part of the changes in wage inequality.

\section{A Brief History of Trucking}

Our interest in examining wage inequality for truck drivers stems from three facts: first, it is a very large occupation (roughly three percent of all employed males); second, there is little reason to believe that SBTC has substantially altered the structure of this labor market; third, truck driving is an occupation that, post-deregulation, experienced substantial real wage declines concurrent with considerable employment growth.

Most research on trucking labor markets attributed the wage decline to the deregulation of trucking in the late 1970s (Rose 1987; Hirsch 1988; Hirsch and Macpherson 1998). Trucking was regulated by the Motor Carrier Act of 1935, which restricted entry onto trucking routes and established rate bureaus, leading to rate setting, with prices in excess of marginal cost. The decrease in market competition resulted in regulatory rents which appeared to have been shared by firms and labor, especially those drivers who were covered by Teamster collective bargaining agreements (Alexis 1998).

Though most of the restrictions were imposed on "for-hire" trucking firms (firms that offer trucking services as their primary business; also referred to as the trucking industry), the regulations also affected private carriage operations within firms (firms that haul their own 
freight). Under regulation, private carriers were only allowed to haul their own freight and could not arrange back hauls or contract out trucking services.

Deregulation of interstate trucking began administratively in the 1970s with loosening entry restrictions and was enacted officially with the Motor Carrier Act of 1980. There was considerable upheaval in trucking, characterized by bankruptcy of incumbent firms and entry of new, often small, for-hire firms. Not surprisingly, the end of regulatory rents resulted in a loss of union power and union density; union membership fell from 55 to $25 \%$ among firms that provided trucking services as their core business (Hirsch and Macpherson 1998).Though the Teamsters still have a presence in trucking, they largely retreated into specialized segments of the market, such as auto hauling and less-than-truckload operations.

Wages declined substantially, though these wage declines differed by segment of the market. Regression analysis by Belzer (1995) suggests that deregulation reduced hourly earnings by approximately 28.6\%. Hirsch (1988) finds that deregulation had little effect on the earnings of non-union drivers, but reduced union drivers' earnings by $12 \%$ relative to non-union drivers. Hirsch and Macpherson (1998) find that deregulation reduced wages in the for-hire sector by $15 \%$ and attribute this to declining union wage premiums.

These studies focus on the period prior to deregulation as well as a limited period postderegulation (typically spanning 1973-early 1990s). In our study, we focus exclusively on the post-deregulation period. Given that deregulation had different impacts on different segments of the truck driving labor force, it is interesting to examine the trends in wage inequality in the new, highly competitive labor market, characterized by an absence of skill-biased technological change. This post-deregulation period is also characterized by the largest changes in the economy-wide wage structure. 


\section{Within-Occupation Wage Inequality and the Trucking Labor Market}

Skill-biased technological change in itself is too coarse a measure to provide a complete account of wage inequality in a specific occupation. Therefore, this section discusses possible sources of within-group occupational wage inequality in general and relates them to the labor market for truck drivers. The sources of within-occupation inequality documented in the literature are trade, industry structure, regulatory regime, managerial strategy, increased occupational migration, minimum wages and union density.

While an increased volume or changed pattern of trade could, certeris paribus, raise wages it would have to impact different sub-groups of drivers differently to cause changes in occupational wage inequality. However, in the current context, trade is unlikely to be important. One can think of the labor market for drivers as three segments: national, regional, and local based upon the type of services one’s employer provides. National carriers generally provide services at all three levels. If trade patterns were to change (eg. higher levels of West Coast trade versus East Coast trade) the type of long haul services would also change (eg. more services between LA and Chicago and less from NY to Chicago), however the type of driver needed would not. The movement of goods into the US from an ocean port via truck generally requires a short dray before the freight is moved to the existing domestic network. Thus, increased trade volumes would merely require more drivers (but not an inherent change in the types of drivers needed) and changed trade patterns would result in more long haul drivers needed in one region versus another. However, since the labor market for long-haul drivers is national (with drivers serving all 48 contiguous states) there would be no resulting regional wage changes that would drive wage differentials within the occupation. 
Changes in within-occupation inequality may also be caused by changes in industry structure and regulatory regime. As discussed in section II, while economic deregulation caused considerable industry upheaval, these changes were felt almost immediately after the Motor Carrier Act of 1980. Moore (1986) reports the number of trucking carriers, relatively stable throughout the 1970s at roughly 16,000, increased from 17,083 in 1979 to 25,722 in 1982 . By examining trends in inequality over time, we can assess the contribution of changes in industry structure due to the change in regulatory regime. However, this is likely to have caused a change in wage structure fairly quickly after deregulation and not likely to be the cause of changed inequality after the late-1980s.

A similar conclusion is likely to be reached with respect to managerial strategy. In fact, regulation, industry structure and managerial strategies are likely highly conflated in trucking. As was discussed in Section II, the period immediately after deregulation saw both consolidation of large firms and the entry of numerous small firms. Thus, the variance in firm size increased after deregulation, which may result in wage dispersion driven by managerial strategies, assuming that small and large firms have systematically different strategies. It is entirely possible that firms within the same industry react differently to a technological impetus by upgrading or deskilling an occupation. Hunter et al. (2001) show that the revolution in information technology had a non-uniform impact on skill content of bank tellers. Interesting here is that both banks basically had the same goal (customer segregation) but pursued it differently leading to increased inequality within the occupation.

In trucking, an example of this is the increased use of technology beginning in the late 1990s that facilitated both truck monitoring and communication between driver and firm. This technology was first adopted by large carriers (not surprising given the economies of scale from 
this type of technology). Unfortunately, our data set does not have information on firm size. However, this technological change is also unlikely to have caused systematic changes in wage inequality. If this technology is productivity improving, the productivity gains are likely to be retained by the firms to generate a return on their investment rather than passed along to the drivers. As the technology is unlikely to have changed the underlying type of labor hired (the educational level of the workforce did not change, indicating that it neither required additional skills nor fewer skills), there should be little change in wage inequality. One caveat is that wages could have increased to compensate drivers for the disutility of being actively monitored. While this is theoretically possible, since the 1930s drivers have been monitored ex post through paper log books, which means there was not likely to be any compensating differential paid for the disamenity of real-time monitoring.

In a series of papers Kambourov and Manovskii (2008, 2009a, 2009b) find that occupational-specific human capital is the most important part of human capital (compared to firm-specific and industry-specific). When mobility patterns of a labor markets change in a way that results in the acquisition of less occupation-specific human capital, occupation mobility has the potential to alter within-occupation wage inequality. However, the share of people entering, leaving and staying the trucking occupation in the period that we are studying is relatively stable (after controlling for the business cycle) which means that occupational mobility is likely not a big concern within truck driving.

The final two factors are the minimum wage and deunionization. While truck drivers are not directly covered by many provisions of the Fair Labor Standards Act their effective hourly wages cannot be below the federal minimum wage. We address this by including a measure of the federal minimum wage in our regression analysis. Finally, compensation patterns differ 
between union and non-union truck drivers. Therefore, the deunionization that followed the deregulation of the industry has the potential to alter wage inequality of truck drivers. We address this by analyzing the evolution of wage inequality for both a union and non-union subsample. We also include a measure of union density in our regression analysis.

\section{Data}

We use data collected by the Bureau of Labor Statistic in its Current Population Survey (CPS) Outgoing Rotation Groups (ORG) files. ${ }^{1}$ The survey is structured such that individuals are interviewed for four months, exit the sample for eight months, then are interviewed again for four months. During the last month of each "stay," earnings data is collected and merged into the annual ORG files. Our analysis uses the files from 1979 through 2009.

Earlier studies analyzing trends in wage inequality also used the March CPS (an annual supplement available from 1963-2004) and added the May CPS files to the ORG files. We solely rely on the ORG files due to larger sample sizes and the lower measurement error pointed out by Lemieux (2006).

The variables used are the hourly real wage, educational attainment, labor market experience (age-education-6), gender, union coverage, race, and region. Six sub-samples are constructed: all employed males, all truck drivers ${ }^{2}$, unionized truck drivers, non-unionized truck drivers, truck drivers employed in the trucking industry (for-hire), and truck drivers employed outside of the trucking industry (private carriage). All subsamples are restricted to individuals age 16-65 years and employed full time (35 or more hours per week). The appendix presents

\footnotetext{
${ }^{1}$ The data files were obtained from the NBER Merged Outgoing Rotation Groups files.

${ }^{2}$ As females comprise less than three percent of the sample of truck drivers, we restrict our sample to males.
} 
descriptive statistics on earnings, education, experience, and union coverage for each subsample. $^{3,}$

In the following sections we document the evolution of wage inequality between the economy-wide male sample and truckers and within the subsamples of truck drivers. We use three measures of wage inequality: the difference in log wages between the $90^{\text {th }}$ and $10^{\text {th }}$ percentiles of the wage distribution in a given year and, similarly, the 90-50 (upper half), and 5010 (lower half) log percentile differences. These differences can be roughly interpreted as the percentage difference in wages between the two respective points in the wage distribution. We also examine changes in overall wage inequality and residual wage inequality, where the latter measures inequality in the distribution of residuals obtained from regressing log wages on three educational dummies (high school, some college, college and more), a quadratic in experience, a full set of interactions between education and experience, dummy variables for black and other races, and a set of regional dummies.

\section{Overall Wage Inequality}

\section{IV.A. Males Economy-wide vs. Truck Drivers}

Figure 1 displays the trend in overall wage inequality as shown by the 90-10 percentile difference over the data period for the economy-wide male sample and truck drivers. The pattern for the economy-wide males is consistent with earlier studies. Wage inequality rises considerably from the early 1980s to the middle 1990s as found by Autor, Katz, and Kearney (2008). The pattern of wage inequality for truck drivers (also Figure 1) is very different from the economywide male sample. Though in the very beginning of the sample period wage inequality of truck

\footnotetext{
${ }^{3}$ For a detailed description of the data please consult Autor et al. (2008) We follow their data construction except that we use the MORG data provided at NBER.org.
} 
drivers appears to have increased, the graph provides evidence the wage inequality has decreased ever since.

\section{FIGURES 1-3 HERE}

Figure 1 provides support for the hypothesis that the time pattern of wage inequality for truck drivers is substantially different than males economy-wide. Figures 2 and 3 further demonstrate this contrast. The 50-10 percentile differential is relatively stable for both groups after the mid1980s. The increase in inequality across the male sample is largely driven by the 90-50 percentile differential, while inequality at the upper end of the distribution decreased for truck drivers. This latter finding is not surprising, given that the increased competition following deregulation should have primarily affected drivers at the upper end of the distribution, who were more likely to have been receiving rents during regulation.

As discussed in section II, the segments of the labor market sharing in the regulatory rents can be defined by both union membership and industry.

\section{IV.B. Union vs. Non-Union}

The trend in mean wages for union members (see appendix) follows that of drivers as a whole: a decline in mean hourly earnings through the mid-1990s and wages slightly decreasing from 1996-2007. Mean wages for nonunion drivers are stable/slightly increasing over the period of study. This finding at the mean supports the earlier findings of Hirsch (1988) that unionized drivers felt the largest impacts of deregulation's impact on the trucking labor market.

Moving from the mean wages to the distribution of wages, Figure 4a continues the analysis of the 90-10 log-wage differential by comparing unionized and non-unionized truckers. Segments of the trucking sector (mostly grocery, car haul, and some less-than-truckload and 
package express) remain heavily unionized, thus different trends in wage inequality can be expected between unionized and non-unionized truck drivers. Due to inconsistency in measuring union membership before 1983, we limit the sample range to 1983-2007.

FIGURE 4 HERE

Figures $4 \mathrm{~b}$ and c show wage inequality for non-unionized drivers declining through the mid1990s and stable thereafter. This trend is solely attributable to declines in inequality in the upper half of the wage distribution, while inequality appears to have increased from 1995-2007 for drivers in the bottom half of the distribution.

The pattern for unionized drivers looks different and its volatility makes it impossible to draw conclusions regarding trends simply by examining the overall ratios.

\section{IV.C. For Hire vs. Private Carriage}

Another factor that could confound the findings for the sample of all truck drivers is the fact that for-hire drivers and private carriage drivers are in distinctly different segments of trucking services. As discussed earlier, the initial regulations facing private carriage and for-hire segments were markedly different and, based on prior research, we would expect the labor markets to react differently to deregulation and subsequent changes to the occupation. Simply looking at the means, however, shows that both groups had similar wage patterns, with wages decreasing through the mid-1990s and increasing from 1996 through 2007 (see appendix).

Figure 5a presents the inequality analysis using the 90-10 log-wage differential to contrasting for-hire and private carriage drivers. The results are very interesting. While Figure 5a displaying the 90-10 differential suggests a similar trend in wage inequality for both groups of 
drivers, Figures 5b and 5c show that merely looking at the whole wage distribution does hides some potentially important facts.

\section{FIGURE 5 HERE}

Figure 5b shows a convergence in wage inequality in the upper-half of the wage distribution for private carriage and for-hire drivers, driven by an increase in wage inequality among for-hire drivers and a decrease in wage inequality among private carriage drivers. This change seems consistent with increased competition in the for-hire segment of trucking services. Figure 5c also provides evidence that wage inequality converged between these groups at the lower end of the distribution, however this appears to be driven by decreased wage dispersion among for-hire drivers.

\section{Residual wage inequality}

As the prior section examines the trends in hourly wages with no controls for individual characteristics, it is logically extended by examining whether changes in worker characteristics post-deregulation are driving the changes in wage distribution. After estimating a wage equation controlling for education, experience, race and region, the $90^{\text {th }}, 50^{\text {th }}$ and $10^{\text {th }}$ log residuals are calculated for each year.

Between-group inequality, typically measured as the difference in earnings of college and high-school educated workers, is not measured for our study. As the majority of truck drivers have high school diploma at their terminal level of education, little would be gained by examining the returns to college versus high school.

Figures 6a-c show that residual inequality of truck drivers has a similar pattern to the unadjusted inequality (figures 1-3). Residual inequality of union and non-union truck drivers 
are compared in Figures 7a-c. The series behave in similar ways until around 2000, when inequality among unionized truck drivers fell. As Figure 7c indicates this decrease seems to have been driven by the decrease in inequality of unionized truck drivers in the lower half of the wage distribution. In all, the patterns of wage inequality in Figures 7a-7c resemble those of Figures 4a-4c, though slightly more muted, indicating that workers characteristics accounted for some of the trends in inequality, but the overall findings of decreased inequality at the upper end of the distribution and increased inequality at lower end of the distribution holds for nonunion truck drivers.

\section{FIGURES 6-8 HERE}

Figures 8a-c compare wage inequality measures between private carriage and for-hire drivers. Differences before 2000 were mostly in levels but after 2000 the data indicates a convergence between the groups, driven by a decrease in wage inequality in the upper half of the distribution for for-hire drivers and an increase in wage inequality in the lower half of the distribution of private carriage drivers.

These stand in contrast to Figures 5a-c. Without controlling individual characteristics, it appeared that 90-10 inequality increased for both for-hire and private carriage drivers through the mid 1990s and then declined thereafter. The residual analysis shows declining inequality in the for-hire segment. This masks the an increase in 90-50 differential through the mid-1990s and decrease thereafter. The lower end of the distribution saw a decrease in inequality over the entire period. The overall trend is what we would expect in the for-hire segment of the industry, as it became much more competitive following deregulation. 
The stable 90-10 residual differentials in private carriage conform to our expectations, however, they mask an increase in 50-10 inequality, which cannot be readily explained by changes in industry structure prompted by deregulation.

\section{Institutional Explanations}

Apart from skill-biased technological change how much did institutional changes affect the evolution of wage inequality of truck drivers? We are trying to provide a preliminary answer in this section. Card and DiNardo (2002) maintain that the falling real value of the minimum wage, especially in the 1980s, was a major cause of increased wage inequality. Autor at al. (2005) weaken this claim by showing that the real value of the minimum wage is also statistically correlated with the development of wage inequality in the upper half of the wage distribution, which is counterintuitive.

In this section we regress the overall 90-10, 90-50, and 50-10 percentile difference of the log real wage on the real value of the federal minimum wage, a measure of economy-wide union coverage $^{4}$, the coefficient of variation for education, the coefficient of variation for experience. We also include a time trend and an indicator variable for years after 1991. We include the post1991 dummy variable since Autor et al. (2008) provide evidence of a slow-down in skill-biased technological change after 1992 in their analysis. We run the regression for every subsample using all years (1979-2009) available and for both overall and residual inequality.

\section{VI.A. Overall Inequality Regressions}

Table 1a reports the results for the 90-10 percentile difference in log real wages. While the real value of the federal minimum wage has the expected sign for the sample of all workers, it is statistically insignificant for all other subsamples. This is not surprising for truck drivers;

\footnotetext{
${ }^{4}$ Since there is no data for 1982 we interpolate.
} 
they are not explicitly covered by the provisions of the Fair Labor Standard Act and though their employers are bound by the federal minimum wage law, there are few official complaints of trucking firms paying less than the minimum wage.

The union coverage variable yields mixed results. While the sign of the effect is largely negative, as expected, it is positive and statistically significant in the sample of union drivers. It is important to note that union density decreased substantially over the time period in question. For truck drivers overall, this resulted in less wage inequality, however, the increased wage dispersion among union truck drivers is likely caused by the fact that the contracts for more recent union drivers are not as lucrative as those who have been drivers since the early 1980s, leading to increased inequality within this subsample.

While the coefficient of variation of education yields negative and significant results for the 90-10 differential across all workers and all male workers, there is no significant effect for truck drivers or any of the driver subsamples. This is logical as the occupation is dominated by those with a high school education and there are little returns for additional education. A similar result is found with respect to the coefficient of variation of experience. It is positive and significant for the overall and all male samples, but not significant for any of the truck driving subsamples.

Assuming that the time trend proxies for SBTC, we find little evidence of SBTC for truck drivers, contrasting sharply with the positive and significant coefficient for the overall sample. For the sample of truck drivers and the sample of for-hire truck drivers we actually find a statistically significant downward trend in overall 90-10 wage inequality.

TABLE 1 HERE 
Tables $1 \mathrm{~b}$-c repeat the regression analysis for the upper (2b) and lower (2c) half of the wage distribution. The results for the 90-50 differential are similar to those found for the whole distribution but the analysis of the lower half of the distribution shows that institutional explanations are not likely to have played a large role in the evolution of overall wage inequality in the trucking sector. Autor et al. (2008) showed that the real value of the federal minimum wage and unionization help explain both the evolution of wage inequality in both the upper and lower half of the wage distribution. They use this as evidence against institution explanations. Our regression results provide further evidence for this conjecture. Tables $1 \mathrm{~b}$ and $1 \mathrm{c}$ show that the two variables are only jointly significant for the 90-50 differential but not in explaining the evolution of wage inequality in the lower half of the wage distribution.

Finally, Appendix B presents regression results with the 90-50-10 wage percentiles as the dependent variables, rather than the wage ratios. For truck drivers the effect of union coverage is highest at the median and below. We see a similar result for coefficient of variation in experience, with higher variation having a larger absolute impact at the lower deciles.

\section{VI.B. Residual Inequality Regressions}

Tables 2a-c repeat the above regression analysis for our measures of residual wage inequality. The results are very similar to those obtained using overall inequality measures as dependent variables. The real value of the federal minimum wage and union membership are jointly significant for the economy-wide and all-male samples, using the 90-10 difference as the dependent variable, but not for any of the trucking subsamples. The results summarized in Tables $2 \mathrm{~b}$ and 2c, however, again show that the results are driven by the effect of the institutional variables on the upper half of the residual wage distribution providing further evidence for an institutional explanation of wage inequality. 


\section{TABLE 2 HERE}

In summary we can state again that the influence of institutional factors like the real value of the federal minimum wage and union coverage have a markedly different influence among truck drivers than in the economy as a whole.

\section{Conclusions}

This paper analyzes the evolution of wage inequality of U.S. truck drivers, comparing this labor market to economy-wide trends for employed males. The analysis showed that wage inequality evolved in a very different manner compared to the economy as a whole. While wage inequality in the whole economy increased during the sample period (1979-2009), the same measures for truck drivers show no such increase. On the contrary, this paper provided evidence that wage inequality for truck drivers has decreased for some sub-groups. This is true for the measures of overall, between-group and within-group inequality. We also find little evidence that the structure of truck drivers wages responds to institutional factors like the real value of the federal minimum wage or union coverage.

These findings are in line with the notion that skill-biased technological change was the main driving force behind the changes in the U.S. wage structure since the trucking industry has not experienced innovations in the last 25 years that would result in an increase in the relative demand for skilled versus unskilled labor. It also provides evidence for the argument that trucking deregulation created a more competitive labor market with a decrease in wage dispersion, as those labor groups that were able to extract rents during the regulatory period were no longer able to maintain their wage advantages in the post-deregulation period. This is particularly evident with the compression of wages at the upper end of the distribution that occurred within the unionized and for-hire segments of the labor force, both sectors that 
experienced rents during regulation. Somewhat surprising is that the nonunion and private carriage segments (who did not receive rents during regulation) have experienced increased in wage inequality at the lower end of the wage distribution, which cannot be explained by changes in worker or economic characteristics. 


\section{References}

Alexis M. (1998) 'Commentary on Earning and Employment in Trucking: Deregulating a Naturally Competitive Industry', In James Peoples, ed. Regulatory Reform and Labor Markets, Norwell, MA: Kluwer Academic Publishers.

Autor D. H. and Dorn D. (2008) 'Inequality and Specialization: The Growth of Low-Skill Service Jobs in the United States', IZA Discussion Paper 4290.

Autor D. H., Katz L.F. and Kearney M.S. (2008) 'Trends in U.S. Wage Inequality: Re-assessing the Revisionists', Review of Economics and Statistics, 90: 300-23.

Auto, D. H., Katz L.F. and Krueger A.B. (1998) 'Computing Inequality: Have Computers Changed the Labor Market?', The Quarterly Journal of Economics, 113: 1169-213.

Autor D. H., Levy F. and Murnane R. J. (2003) 'The Skill Content of Recent Technological Change: An Empirical Exploration.', The Quarterly Journal of Economics, 118: 1279-1334.

Baker G. P. and Hubbard T. N. (2004) 'Contractibility and Asset Ownership: On-board Computers and Governance in U. S. Trucking', Quarterly Journal of Economics, 119: 1443-79.

Belzer M. H. (1995) 'Collective Bargaining after Deregulation: Do the Teamsters Still Count?', Industrial and Labor Relations Review, 48: 636-55.

Card D. and DiNardo J.E. (2002) 'Skill-biased Technological Change and Rising Wage Inequality: Some Problems and Puzzles', Journal of Labor Economics, 20: 733-83.

Goldin C., and Katz L.F. (2008) The Race between Education and Technology, Cambridge, MA, Harvard University Press.

Hirsch B.T. (1988) 'Trucking Regulation, Unionization, and Labor Earnings: 1973-85', The Journal of Human Resources, 23: 296-319.

Hirsch B. T., and Macpherson D.A. (1998) 'Earnings and Employment in Trucking: Deregulating a Naturally Competitive Industry.' In Peoples J. ed., Regulatory Reform and Labor Markets, Norwell, MA: Kluwer Academic Publishers.

Hunter L.W., Bernhardt A., Hughes K.L. and Skuratowicz E. (2001) 'It's Not Just the ATMs: Technology, Firm Strategies, and Earnings in Retail Banking', Industrial and Labor Relations Review, 54: 402-24.

Juhn C. Murphy K.M. and Pierce B. (1993) 'Wage Inequality and the Rise in Returns to Skill,' The Journal of Political Economy, 101: 410-42. 
Katz L. F. and Autor D.H. (1999) 'Changes in the Wage Structure and Earnings Inequality', In Ashenfelter O. and Card D.E. eds, Handbook of Labor Economics, Volume 3, Part 1, Amsterdam: Elsevier.

Kambourov G. and Manovskii I. (2008) 'Rising Occupational and Industry Mobility in the United States: 1968-1997', International Economic Review, 49: 41-79.

Kambourov G., and Manovskii I. (2009a) 'Occupational Specificity of Human Capital', International Economic Review, 79: 63-115.

Kambourov G. and Manovskii I. (2009b) 'Occupational Mobility and Wage Inequality', Review of Economic Studies, 76: 731-759.

Lemieux T. (2006) 'Increasing Residual Wage Inequality: Composition Effects, Noisy Data, or Rising Demand for Skill?', The American Economic Review, 96: 461-98.

Levy F. and Murnane R. J. (1992) 'U.S. Earnings Levels and Earnings Inequality: A Review of Recent Trends and Proposed Explanations', Journal of Economic Literature, 30: 1333-81.

Moore T. G. (1986) ' Rail and Trucking Deregulation,' In Weiss L.W. and Klass M.W. eds.

Regulatory Reform: What Actually Happened, Boston: Little, Brown, and Company.

Moretti E. (2008) 'Real Wage Inequality', NBER Working Paper 14370.

Rose N. L. (1987) 'Labor rent sharing and regulation: Evidence from the trucking industry. The Journal of Political Economy, 95: 1146-78. 
Figure 1: 90-10 Overall Male Sample/Truckers

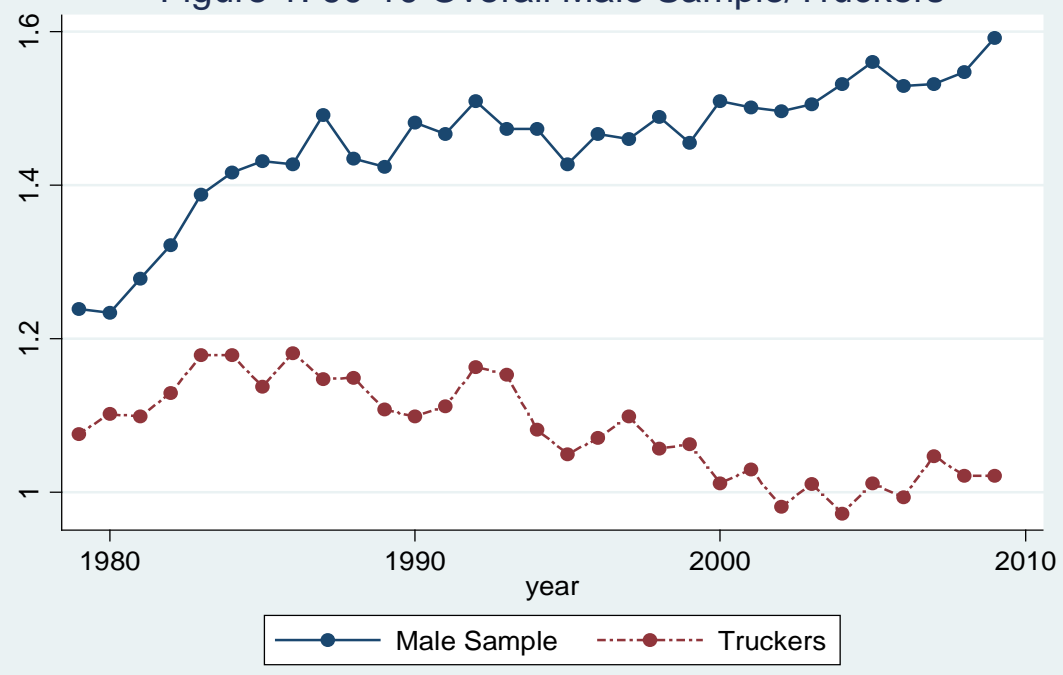

Figure 2: 90-50 Overall Male Sample/Truckers

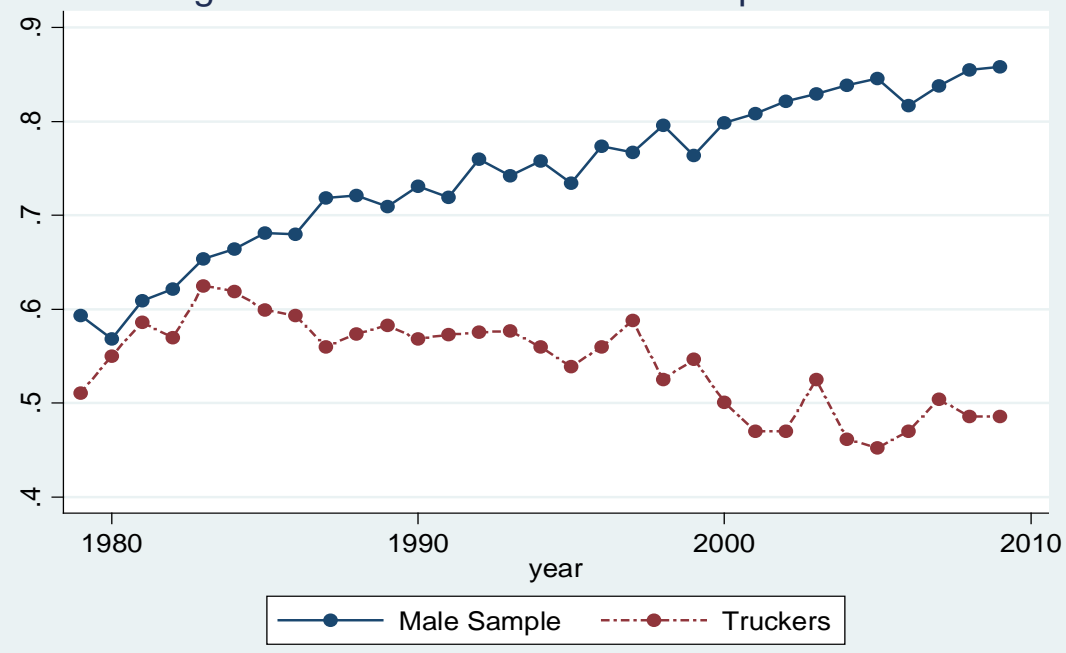

Figure 3: 50-10 Overall Male Sample/Truckers

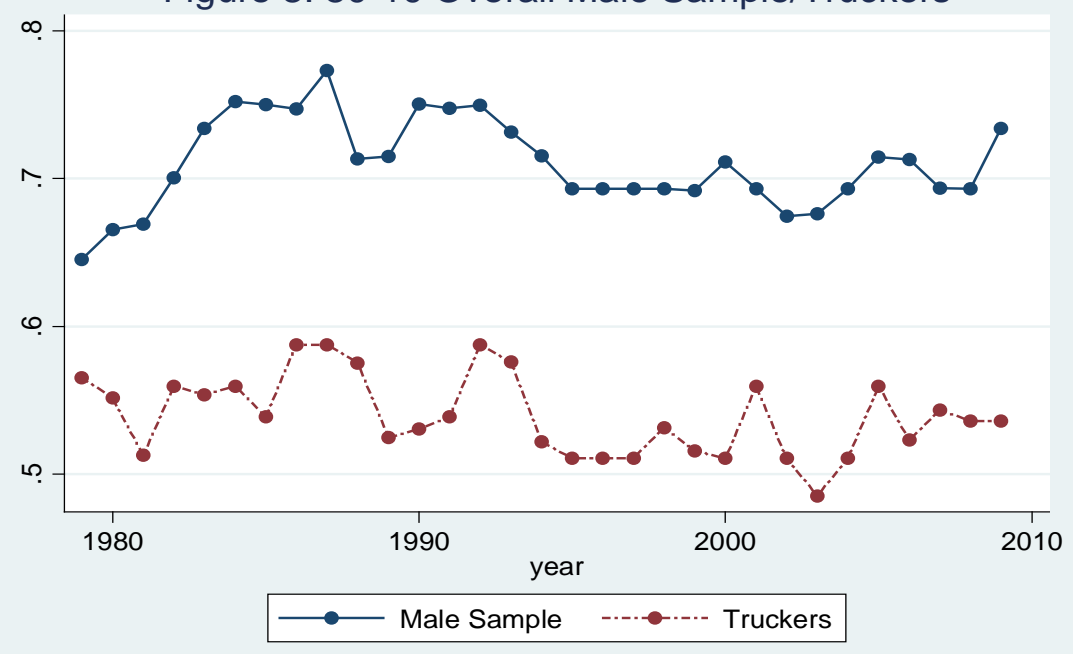


Figure 4a: 90-10 Overall Truckers Union vs. Non-Union
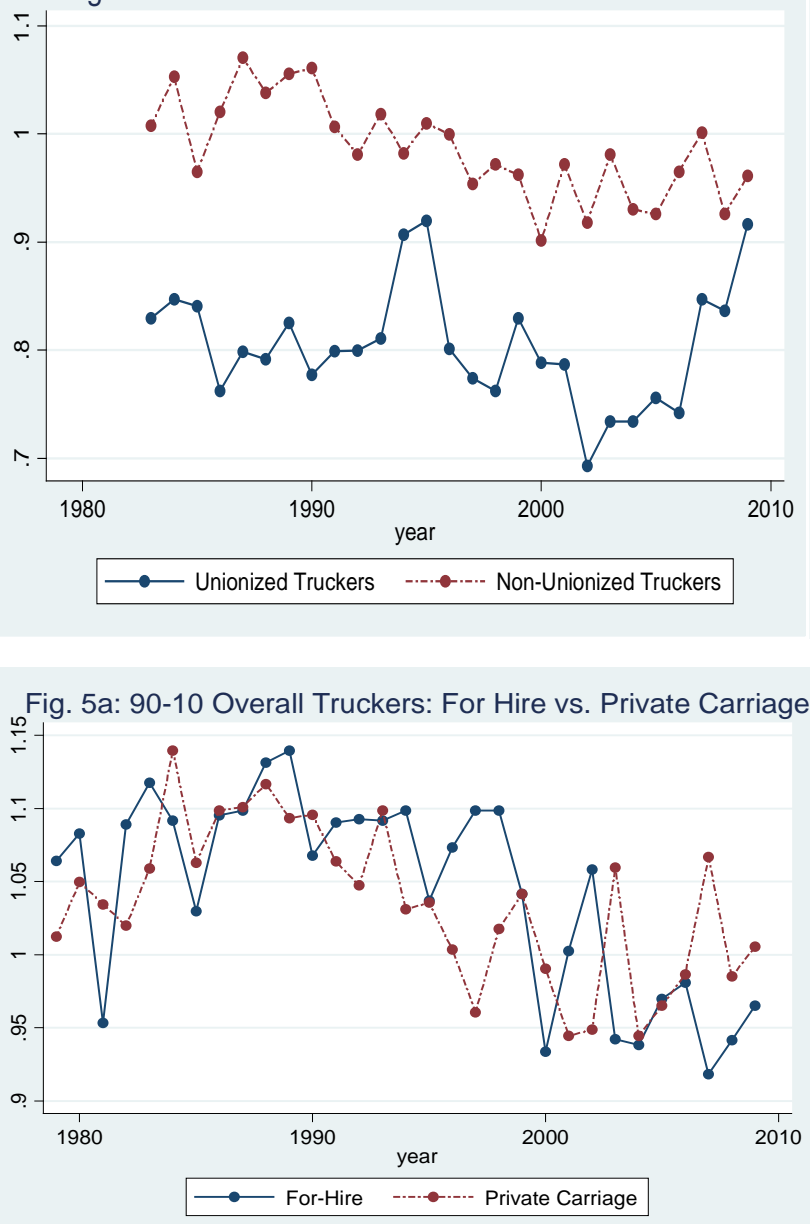

Figure 4b: 90-50 Overall Truckers Union vs. Non-Union

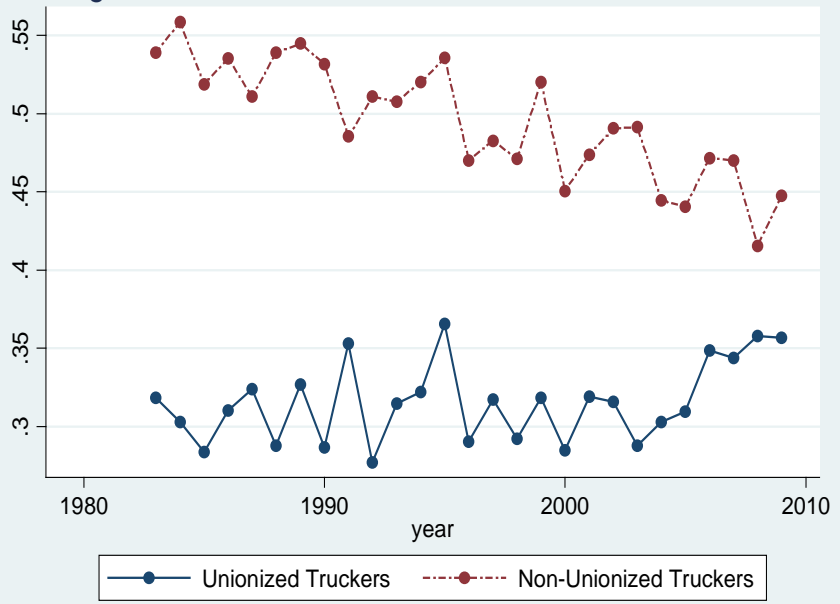

Fig. 5b: $90-50$ Overall Truckers: For Hire vs. Private Carriage

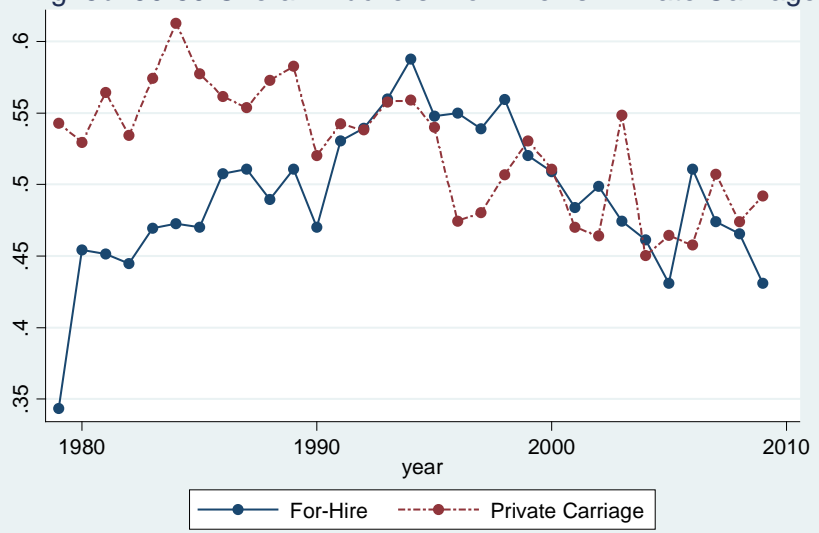

Figure 4c: 50-10 Overall Truckers Union vs. Non-Union

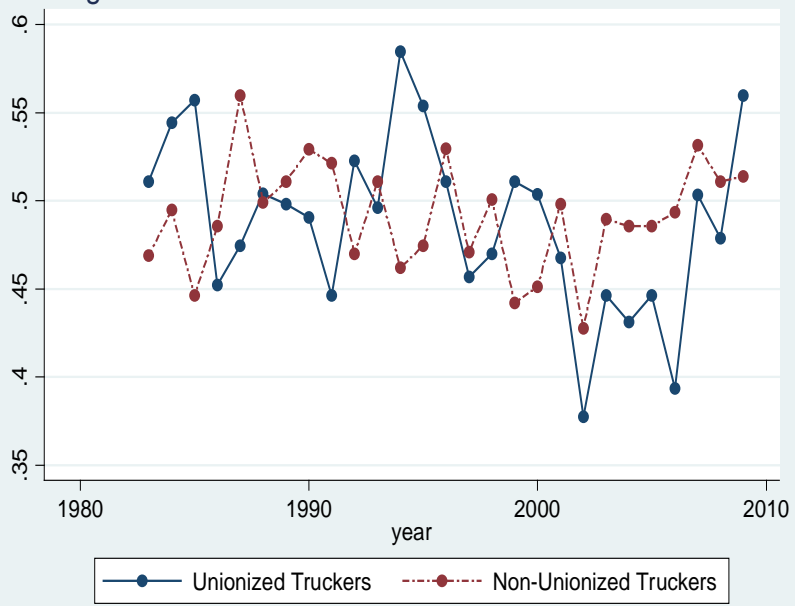

Fig. Sc: 50-10 Overall Truckers: For Hire vs. Private Carriage

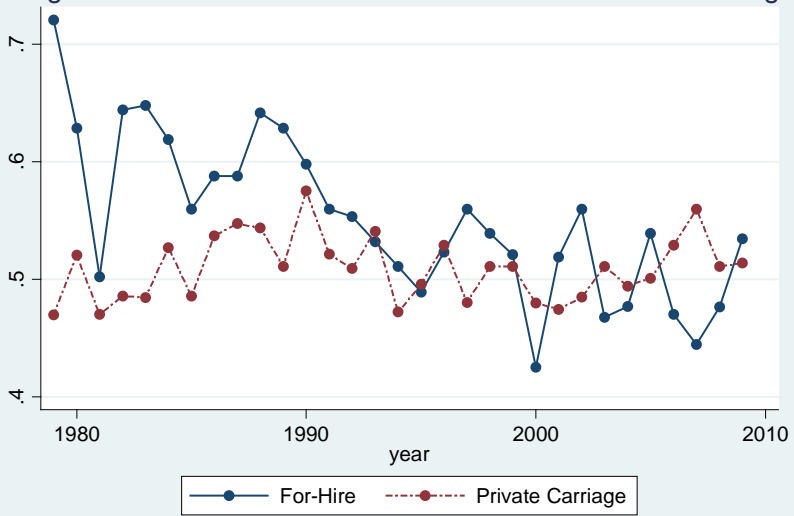



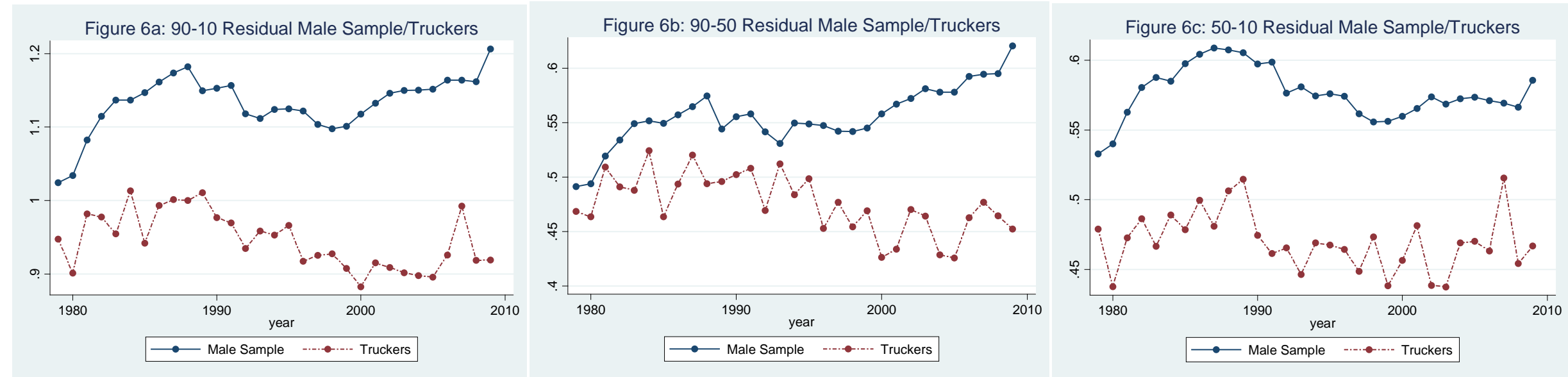

Fig. 7a: 90-10 ResidualTruckers Union vs. Non-Union

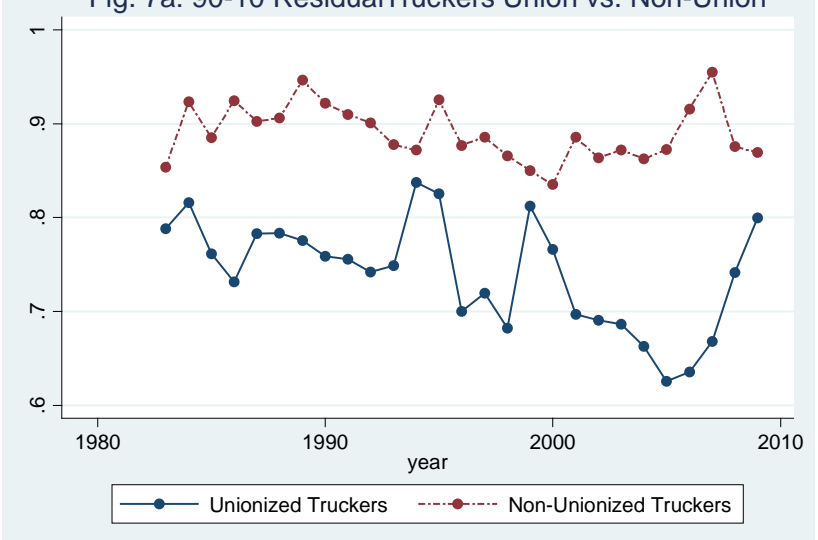

Fig. 7b: 90-50 ResidualTruckers Union vs. Non-Union

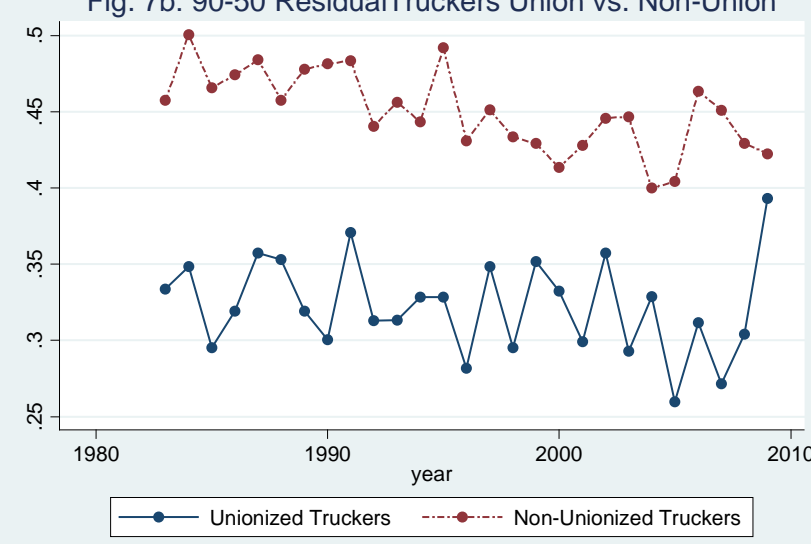

Fig. 7c: 50-10 ResidualTruckers Union vs. Non-Union

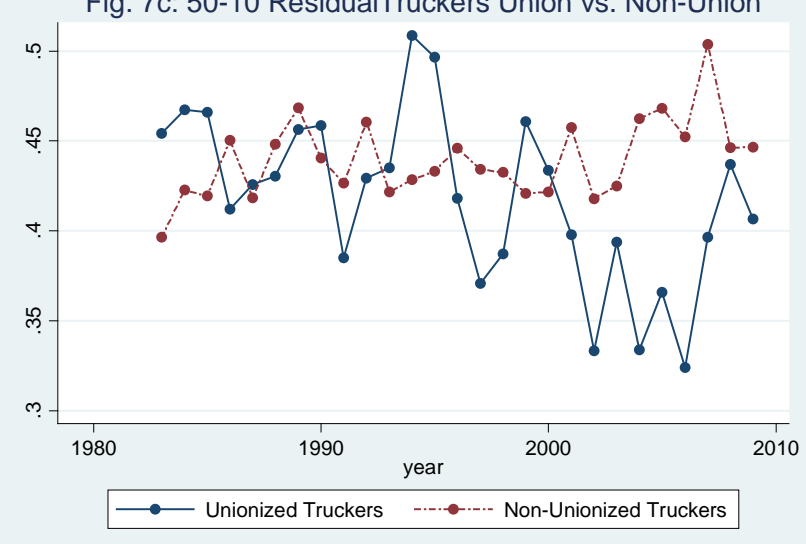



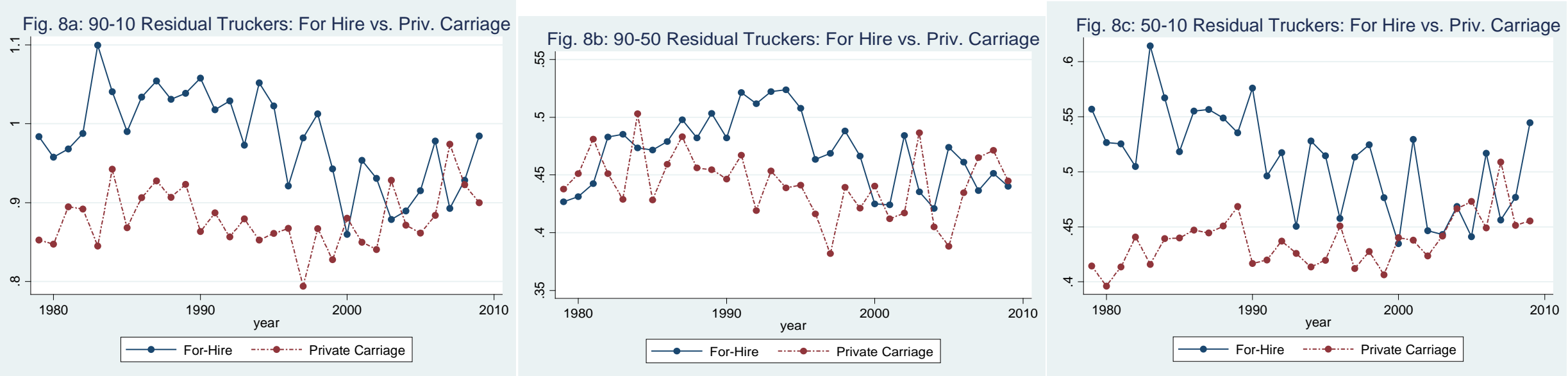
Table 1a: OLS-Regression of the Overall 90-10 Differential

\begin{tabular}{|c|c|c|c|c|c|c|c|c|c|c|c|c|c|}
\hline & All & & All-Male & & Truckers & & Union & & Non-Union & & For-Hir & & Private \\
\hline $\begin{array}{l}\text { Real Value of Fed. Min. } \\
\text { Wage }\end{array}$ & $\begin{array}{l}-0.029 \\
-(2.03)\end{array}$ & $* *$ & $\begin{array}{l}-0.008 \\
-(0.41)\end{array}$ & & $\begin{array}{l}0.016 \\
(0.95)\end{array}$ & & $\begin{array}{l}0.021 \\
(0.52)\end{array}$ & & $\begin{array}{l}-0.016 \\
-(0.89)\end{array}$ & & $\begin{array}{l}0.005 \\
(0.17)\end{array}$ & & $\begin{array}{l}-0.023 \\
-(0.85)\end{array}$ \\
\hline Union Coverage & $\begin{array}{l}-0.006 \\
-(0.57)\end{array}$ & & $\begin{array}{l}-0.019 \\
-(1.71)\end{array}$ & $*$ & $\begin{array}{l}-0.017 \\
-(2.34)\end{array}$ & $* *$ & $\begin{array}{r}0.036 \\
(1.69)\end{array}$ & $*$ & $\begin{array}{r}0.0004 \\
(0.05)\end{array}$ & & $\begin{array}{l}-0.028 \\
-(2.62)\end{array}$ & $* * *$ & $\begin{array}{l}-0.006 \\
-(0.67)\end{array}$ \\
\hline Year & $\begin{array}{l}0.007 \\
(1.86)\end{array}$ & $*$ & $\begin{array}{r}0.003 \\
(0.64)\end{array}$ & & $\begin{array}{l}-0.012 \\
-(3.18)\end{array}$ & $* * *$ & $\begin{array}{r}0.011 \\
(1.55)\end{array}$ & & $\begin{array}{l}-0.005 \\
-(1.62)\end{array}$ & & $\begin{array}{l}-0.023 \\
-(3.34)\end{array}$ & $* * *$ & $\begin{array}{l}-0.003 \\
-(0.55)\end{array}$ \\
\hline Year $>=1992$ & $\begin{array}{r}0.00001 \\
(0.50)\end{array}$ & & $\begin{array}{r}-0.00002 \\
-(0.89)\end{array}$ & & $\begin{array}{r}-0.00001 \\
-(0.40)\end{array}$ & & $\begin{array}{r}0.00003 \\
(1.17)\end{array}$ & & $\begin{array}{r}-0.00002 \\
-(1.92)\end{array}$ & $*$ & $\begin{array}{r}0.00002 \\
(1.44)\end{array}$ & & $\begin{array}{r}-0.00002 \\
-(1.62)\end{array}$ \\
\hline Coeff. Var. Edu & $\begin{array}{l}-1.963 \\
-(1.96)\end{array}$ & $* *$ & $\begin{array}{l}-1.059 \\
-(1.07)\end{array}$ & & $\begin{array}{l}0.106 \\
(0.07)\end{array}$ & & $\begin{array}{l}-0.875 \\
-(1.32)\end{array}$ & & $\begin{array}{l}1.807 \\
(1.19)\end{array}$ & & $\begin{array}{r}1.274 \\
(1.02)\end{array}$ & & $\begin{array}{l}-0.845 \\
-(0.64)\end{array}$ \\
\hline Coeff. Var. Exp & $\begin{array}{r}0.458 \\
(4.23)\end{array}$ & $* * *$ & $\begin{array}{r}0.325 \\
(2.48)\end{array}$ & $* *$ & $\begin{array}{r}0.034 \\
(1.44)\end{array}$ & & $\begin{array}{r}0.006 \\
(0.59)\end{array}$ & & $\begin{array}{l}-0.013 \\
-(0.65)\end{array}$ & & $\begin{array}{l}0.005 \\
(0.23)\end{array}$ & & $\begin{array}{l}0.003 \\
(0.12)\end{array}$ \\
\hline $\begin{array}{c}\text { P-value of Joint } \\
\text { Hypothesis I }\end{array}$ & 0.001 & $* * *$ & 0.061 & $*$ & 0.295 & & 0.395 & & 0.441 & & 0.455 & & 0.812 \\
\hline $\begin{array}{c}\text { P-value of Joint } \\
\text { Hypothesis II }\end{array}$ & 0.014 & $* *$ & 0.030 & $* *$ & 0.081 & $*$ & 0.130 & & 0.676 & & 0.003 & $* * *$ & 0.199 \\
\hline R-Squared & 0.928 & & 0.895 & & 0.712 & & 0.261 & & 0.613 & & 0.589 & & 0.515 \\
\hline
\end{tabular}

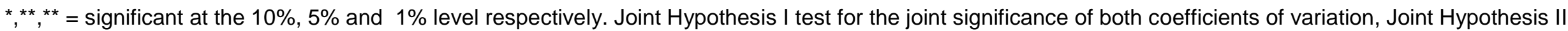
tests for the joint significance of the real value of the minimum wage and Union Coverage. 
Table 1b: OLS-Regression of the Overall 90-50 Differential

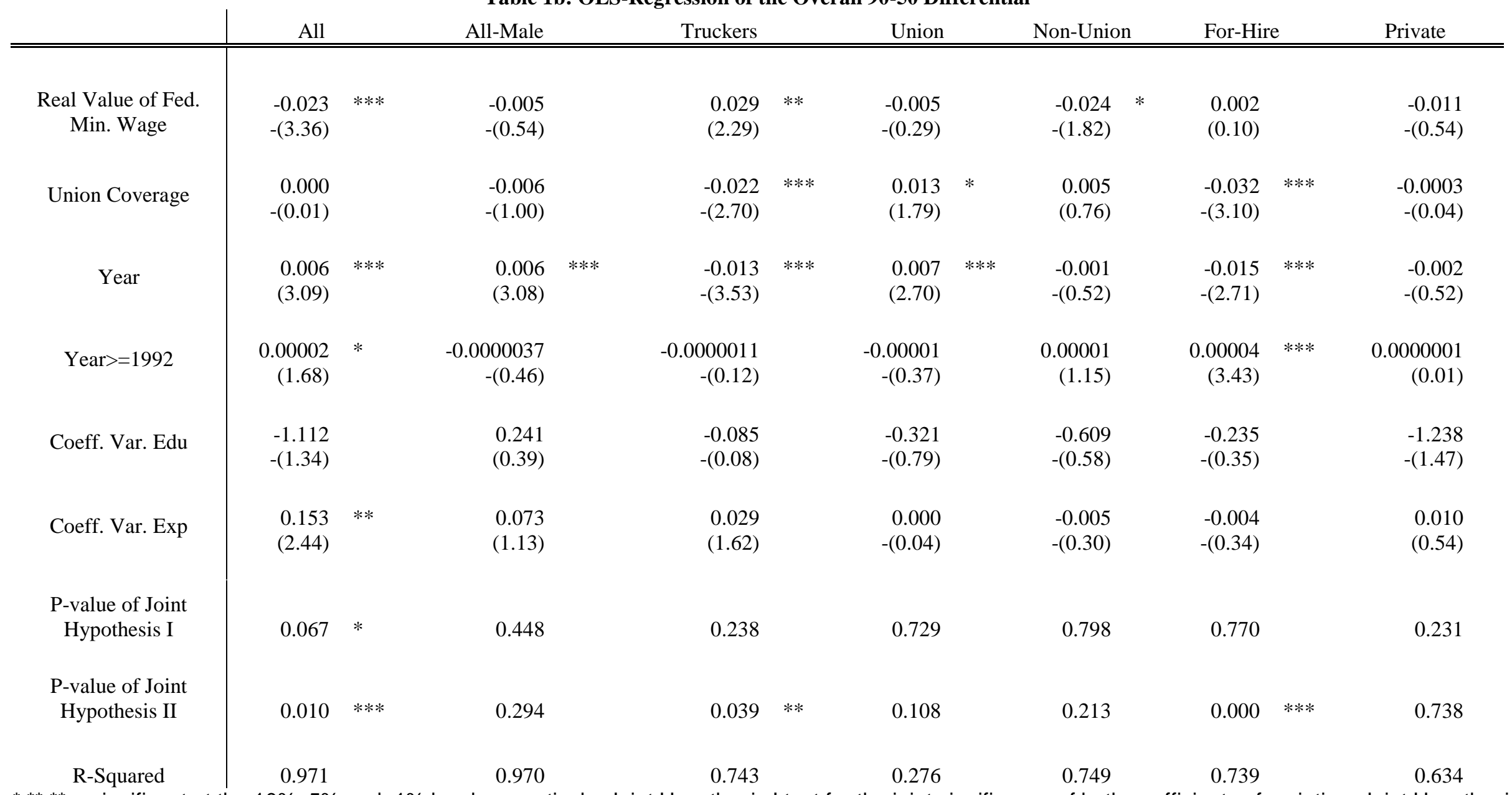

${ }_{*}^{* * *, * *}=$ significant at the $10 \%, 5 \%$ and $1 \%$ level respectively. Joint Hypothesis I test for the joint significance of both coefficients of variation, Joint Hypothesis II tests for the joint significance of the real value of the minimum wage and Union Coverage. 
Table 1c: OLS-Regression of the Overall 50-10 Differential

\begin{tabular}{|c|c|c|c|c|c|c|c|c|c|c|c|c|c|}
\hline & All & & All-Male & & Truckers & Union & & Non-Unio & & For-Hire & & Private & \\
\hline $\begin{array}{c}\text { Real Value of Fed. Min. } \\
\text { Wage }\end{array}$ & $\begin{array}{l}-0.007 \\
-(0.55)\end{array}$ & & $\begin{array}{l}-0.002 \\
-(0.18)\end{array}$ & & $\begin{array}{l}-0.013 \\
-(0.92)\end{array}$ & $\begin{array}{r}0.025 \\
(0.76)\end{array}$ & & $\begin{array}{r}0.008 \\
(0.86)\end{array}$ & & $\begin{array}{r}0.003 \\
(0.12)\end{array}$ & & $\begin{array}{l}-0.013 \\
-(1.03)\end{array}$ & \\
\hline Union Coverage & $\begin{array}{l}-0.006 \\
-(0.65)\end{array}$ & & $\begin{array}{l}-0.013 \\
-(1.60)\end{array}$ & & $\begin{array}{r}0.005 \\
(0.98)\end{array}$ & $\begin{array}{r}0.022 \\
(1.14)\end{array}$ & & $\begin{array}{l}-0.005 \\
-(0.75)\end{array}$ & & $\begin{array}{r}0.004 \\
(0.33)\end{array}$ & & $\begin{array}{l}-0.006 \\
-(1.02)\end{array}$ & \\
\hline Year & $\begin{array}{r}0.001 \\
(0.35)\end{array}$ & & $\begin{array}{l}-0.003 \\
-(1.05)\end{array}$ & & $\begin{array}{r}0.001 \\
(0.18)\end{array}$ & $\begin{array}{r}0.004 \\
(0.54)\end{array}$ & & $\begin{array}{l}-0.004 \\
-(1.32)\end{array}$ & & $\begin{array}{l}-0.008 \\
-(1.36)\end{array}$ & & $\begin{array}{l}-0.001 \\
-(0.26)\end{array}$ & \\
\hline Year $>=1992$ & $\begin{array}{r}-0.00001 \\
-(1.25)\end{array}$ & & $\begin{array}{r}-0.00001 \\
-(0.81)\end{array}$ & & $\begin{array}{r}-0.00001 \\
-(0.47)\end{array}$ & $\begin{array}{r}0.00004 \\
(1.79)\end{array}$ & $*$ & $\begin{array}{r}-0.00003 \\
-(3.88)\end{array}$ & $* * *$ & $\begin{array}{r}-0.00002 \\
-(2.19)\end{array}$ & $* *$ & $\begin{array}{r}-0.00002 \\
-(2.36)\end{array}$ & $* *$ \\
\hline Coeff. Var. Edu & $\begin{array}{l}-0.851 \\
-(0.94)\end{array}$ & & $\begin{array}{l}-1.300 \\
-(1.35)\end{array}$ & & $\begin{array}{r}0.190 \\
(0.24)\end{array}$ & $\begin{array}{l}-0.554 \\
-(0.89)\end{array}$ & & $\begin{array}{r}2.416 \\
(1.97)\end{array}$ & $* *$ & $\begin{array}{r}1.509 \\
(1.59)\end{array}$ & & $\begin{array}{r}0.394 \\
(0.52)\end{array}$ & \\
\hline Coeff. Var. Exp & $\begin{array}{r}0.305 \\
(3.62)\end{array}$ & $* * *$ & $\begin{array}{l}0.252 \\
(2.57)\end{array}$ & $* *$ & $\begin{array}{l}0.005 \\
(0.29)\end{array}$ & $\begin{array}{l}0.007 \\
(0.86)\end{array}$ & & $\begin{array}{l}-0.008 \\
-(0.63)\end{array}$ & & $\begin{array}{l}0.008 \\
(0.46)\end{array}$ & & $\begin{array}{l}-0.007 \\
-(0.58)\end{array}$ & \\
\hline $\begin{array}{l}\text { P-value of Joint } \\
\text { Hypothesis I }\end{array}$ & 0.005 & $* * *$ & 0.045 & $* *$ & 0.933 & 0.506 & & 0.077 & * & 0.182 & & 0.756 & \\
\hline $\begin{array}{c}\text { P-value of Joint } \\
\text { Hypothesis II }\end{array}$ & 0.214 & & 0.149 & & 0.581 & 0.229 & & 0.654 & & 0.842 & & 0.110 & \\
\hline R-Squared & 0.607 & & 0.545 & & 0.220 & 0.339 & & 0.350 & & 0.674 & & 0.300 & \\
\hline
\end{tabular}

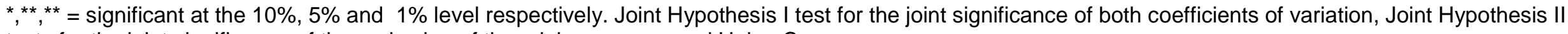
tests for the joint significance of the real value of the minimum wage and Union Coverage. 
Table 2a: OLS-Regression of the Residual 90-10 Differential

\begin{tabular}{|c|c|c|c|c|c|c|c|c|c|c|c|c|c|}
\hline \multicolumn{14}{|c|}{ 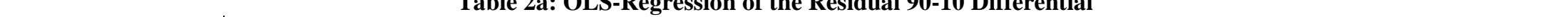 } \\
\hline & All & & All-Male & & Truckers & & Union & Non-Unio & & For-Hire & & Private & \\
\hline $\begin{array}{l}\text { Real Value of Fed. } \\
\text { Min. Wage }\end{array}$ & $\begin{array}{l}-0.018 \\
-(2.74)\end{array}$ & $* * *$ & $\begin{array}{l}-0.015 \\
-(1.76)\end{array}$ & $*$ & $\begin{array}{l}-0.016 \\
-(1.11)\end{array}$ & & $\begin{array}{r}0.029 \\
(0.76)\end{array}$ & $\begin{array}{l}-0.025 \\
-(1.88)\end{array}$ & $*$ & $\begin{array}{l}-0.006 \\
-(0.16)\end{array}$ & & $\begin{array}{l}-0.023 \\
-(1.17)\end{array}$ & \\
\hline Union Coverage & $\begin{array}{l}-0.008 \\
-(2.16)\end{array}$ & $* *$ & $\begin{array}{l}-0.006 \\
-(1.20)\end{array}$ & & $\begin{array}{l}-0.005 \\
-(0.89)\end{array}$ & & $\begin{array}{l}0.016 \\
(0.78)\end{array}$ & $\begin{array}{l}-0.002 \\
-(0.23)\end{array}$ & & $\begin{array}{l}-0.017 \\
-(1.49)\end{array}$ & & $\begin{array}{l}0.004 \\
(0.52)\end{array}$ & \\
\hline Year & $\begin{array}{l}0.005 \\
(2.68)\end{array}$ & $* * *$ & $\begin{array}{r}0.004 \\
(1.66)\end{array}$ & $*$ & $\begin{array}{l}-0.005 \\
-(1.98)\end{array}$ & $* *$ & $\begin{array}{l}0.001 \\
(0.18)\end{array}$ & $\begin{array}{l}-0.002 \\
-(0.69)\end{array}$ & & $\begin{array}{l}-0.015 \\
-(1.80)\end{array}$ & $*$ & $\begin{array}{r}0.004 \\
(1.08)\end{array}$ & \\
\hline Year $>=1992$ & $\begin{array}{r}-0.00003 \\
-(6.75)\end{array}$ & $* * *$ & $\begin{array}{r}-0.00003 \\
-(4.78)\end{array}$ & $* * *$ & $\begin{array}{r}-0.00003 \\
-(3.35)\end{array}$ & $* * *$ & $\begin{array}{r}0.00001 \\
(0.59)\end{array}$ & $\begin{array}{r}-0.00002 \\
-(2.31)\end{array}$ & $* *$ & $\begin{array}{r}-0.00001 \\
-(0.50)\end{array}$ & & $\begin{array}{r}-0.00004 \\
-(3.95)\end{array}$ & $* * *$ \\
\hline Coeff. Var. Edu & $\begin{array}{l}-1.388 \\
-(5.60)\end{array}$ & $* * *$ & $\begin{array}{l}-1.908 \\
-(4.43)\end{array}$ & $* * *$ & $\begin{array}{l}1.726 \\
(1.70)\end{array}$ & $*$ & $\begin{array}{l}-0.520 \\
-(0.89)\end{array}$ & $\begin{array}{l}1.421 \\
(1.36)\end{array}$ & & $\begin{array}{l}1.417 \\
(0.90)\end{array}$ & & $\begin{array}{r}0.898 \\
(0.91)\end{array}$ & \\
\hline Coeff. Var. Exp & $\begin{array}{l}0.387 \\
(6.64)\end{array}$ & $* * *$ & $\begin{array}{l}0.356 \\
(4.93)\end{array}$ & $* * *$ & $\begin{array}{l}0.005 \\
(0.26)\end{array}$ & & $\begin{array}{l}-0.010 \\
-(0.78)\end{array}$ & $\begin{array}{l}-0.018 \\
-(1.20)\end{array}$ & & $\begin{array}{l}-0.016 \\
-(0.71)\end{array}$ & & $\begin{array}{l}-0.011 \\
-(0.59)\end{array}$ & \\
\hline $\begin{array}{c}\text { P-value of Joint } \\
\text { Hypothesis I }\end{array}$ & 0.000 & $* * *$ & 0.000 & $* * *$ & 0.154 & & 0.550 & 0.318 & & 0.648 & & 0.554 & \\
\hline $\begin{array}{l}\text { P-value of Joint } \\
\text { Hypothesis II }\end{array}$ & 0.001 & $* * *$ & 0.023 & $* *$ & 0.096 & $*$ & 0.303 & 0.102 & & 0.026 & $* *$ & 0.408 & \\
\hline R-Squared & 0.947 & & 0.881 & & 0.595 & & 0.429 & 0.451 & & 0.480 & & 0.349 & \\
\hline
\end{tabular}

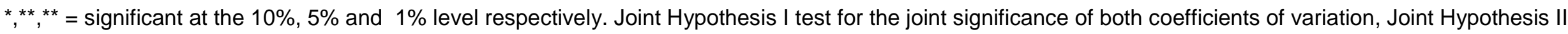
tests for the joint significance of the real value of the minimum wage and Union Coverage. 
Table 2b: OLS-Regression of the Residual 90-50 Differential

\begin{tabular}{|c|c|c|c|c|c|c|c|c|c|c|c|c|c|}
\hline & \multicolumn{2}{|l|}{ All } & \multicolumn{2}{|l|}{ All-Male } & \multicolumn{2}{|l|}{ Truckers } & \multicolumn{2}{|l|}{ Union } & Non-Union & \multicolumn{2}{|c|}{ For-Hire } & \multicolumn{2}{|l|}{ Private } \\
\hline $\begin{array}{l}\text { Real Value of Fed. } \\
\text { Min. Wage }\end{array}$ & $\begin{array}{l}-0.004 \\
-(1.33)\end{array}$ & & $\begin{array}{l}-0.005 \\
-(0.93)\end{array}$ & & $\begin{array}{l}-0.001 \\
-(0.10)\end{array}$ & & $\begin{array}{l}0.026 \\
(1.57)\end{array}$ & & $\begin{array}{l}-0.008 \\
-(0.54)\end{array}$ & $\begin{array}{l}-0.016 \\
-(1.20)\end{array}$ & & $\begin{array}{l}-0.002 \\
-(0.11)\end{array}$ & \\
\hline Union Coverage & $\begin{array}{l}-0.002 \\
-(1.09)\end{array}$ & & $\begin{array}{l}-0.004 \\
-(1.19)\end{array}$ & & $\begin{array}{l}-0.006 \\
-(1.31)\end{array}$ & & $\begin{array}{l}-0.004 \\
-(0.41)\end{array}$ & & $\begin{array}{r}0.000 \\
-(0.07)\end{array}$ & $\begin{array}{l}-0.011 \\
-(1.81)\end{array}$ & $*$ & $\begin{array}{r}0.000 \\
-(0.03)\end{array}$ & \\
\hline Year & $\begin{array}{l}0.004 \\
(4.68)\end{array}$ & $* * *$ & $\begin{array}{l}0.003 \\
(2.75)\end{array}$ & $* * *$ & $\begin{array}{l}-0.006 \\
-(2.47)\end{array}$ & $* *$ & $\begin{array}{l}-0.001 \\
-(0.30)\end{array}$ & & $\begin{array}{l}-0.002 \\
-(0.87)\end{array}$ & $\begin{array}{l}-0.009 \\
-(2.11)\end{array}$ & $* *$ & $\begin{array}{l}0.001 \\
(0.17)\end{array}$ & \\
\hline Year $>=1992$ & $\begin{array}{r}-0.00001 \\
-(5.50)\end{array}$ & $* * *$ & $\begin{array}{r}-0.00001 \\
-(3.39)\end{array}$ & $* * *$ & $\begin{array}{r}-0.00002 \\
-(2.28)\end{array}$ & $* *$ & $\begin{array}{r}-0.00002 \\
-(1.58)\end{array}$ & & $\begin{array}{r}-0.00001 \\
-(1.42)\end{array}$ & $\begin{array}{r}0.00001 \\
(1.00)\end{array}$ & & $\begin{array}{r}-0.00002 \\
-(3.13)\end{array}$ & $* * *$ \\
\hline Coeff. Var. Edu & $\begin{array}{l}-0.942 \\
-(4.98)\end{array}$ & $* * *$ & $\begin{array}{l}-1.451 \\
-(5.14)\end{array}$ & $* * *$ & $\begin{array}{l}1.346 \\
(1.58)\end{array}$ & & $\begin{array}{r}0.015 \\
(0.04)\end{array}$ & & $\begin{array}{r}0.592 \\
(0.68)\end{array}$ & $\begin{array}{r}0.490 \\
(0.67)\end{array}$ & & $\begin{array}{l}0.340 \\
(0.41)\end{array}$ & \\
\hline Coeff. Var. Exp & $\begin{array}{l}0.185 \\
(6.98)\end{array}$ & $* * *$ & $\begin{array}{r}0.179 \\
(4.75)\end{array}$ & $* * *$ & $\begin{array}{l}0.008 \\
(0.49)\end{array}$ & & $\begin{array}{l}-0.018 \\
-(4.00)\end{array}$ & $* * *$ & $\begin{array}{l}-0.010 \\
-(0.98)\end{array}$ & $\begin{array}{l}0.008 \\
(0.63)\end{array}$ & & $\begin{array}{l}-0.009 \\
-(0.52)\end{array}$ & \\
\hline $\begin{array}{c}\text { P-value of Joint } \\
\text { Hypothesis I }\end{array}$ & 0.000 & $* * *$ & 0.000 & $* * *$ & 0.169 & & 0.003 & $* * *$ & 0.586 & 0.480 & & 0.773 & \\
\hline $\begin{array}{l}\text { P-value of Joint } \\
\text { Hypothesis II }\end{array}$ & 0.109 & & 0.076 & $*$ & 0.203 & & 0.272 & & 0.774 & 0.000 & $* * *$ & 0.972 & \\
\hline R-Squared & 0.954 & & 0.916 & & 0.515 & & 0.399 & & 0.555 & 0.478 & & 0.257 & \\
\hline
\end{tabular}

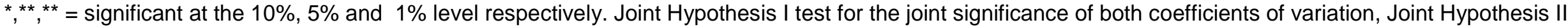
tests for the joint significance of the real value of the minimum wage and Union Coverage. 
Table 2c: OLS-Regression of the Residual 50-10 Differential

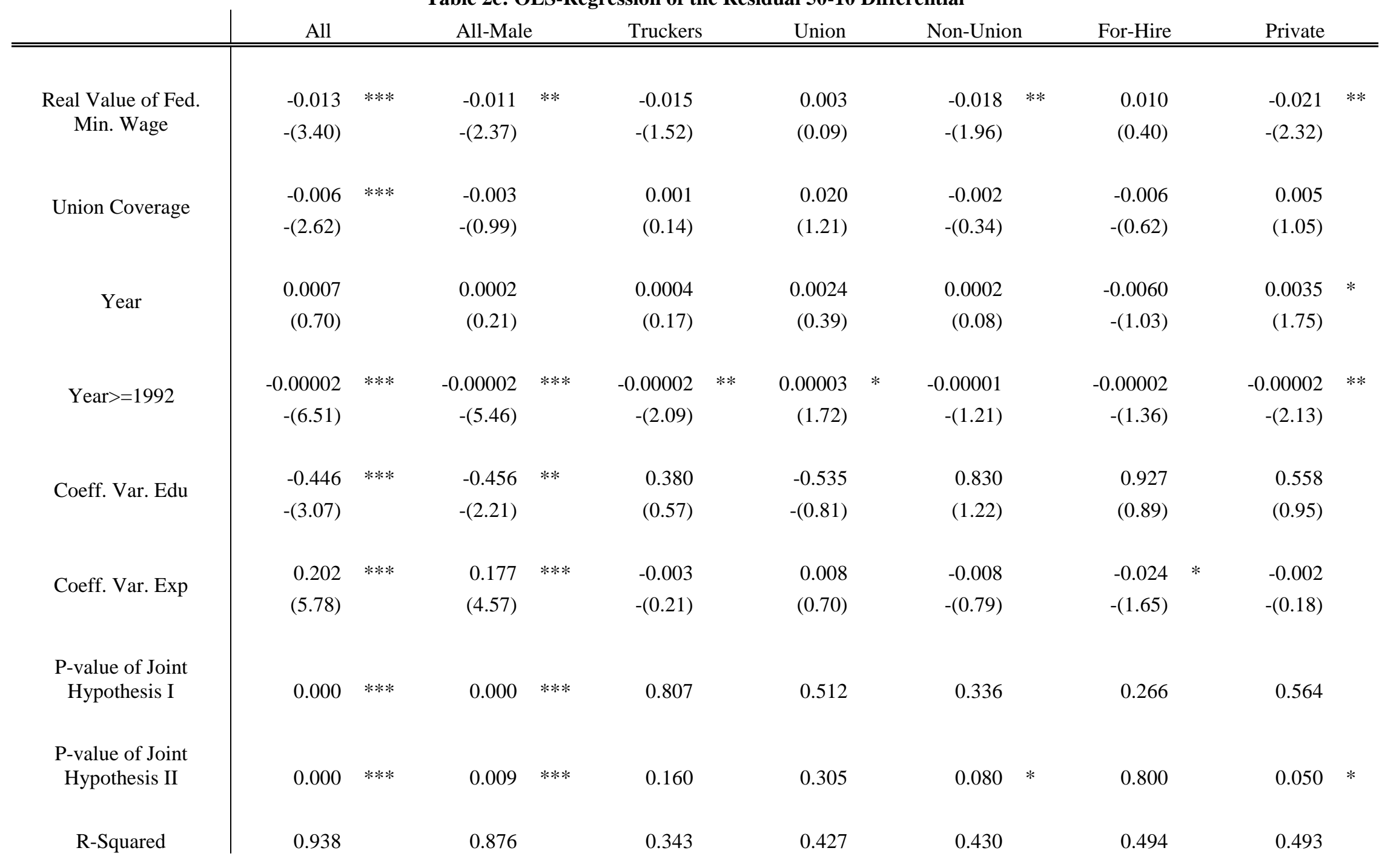

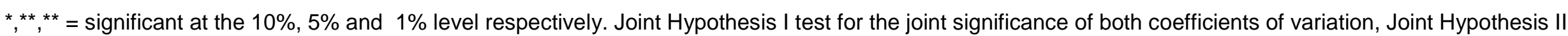
tests for the joint significance of the real value of the minimum wage and Union Coverage. 
Appendix: Descriptive Statistics on the Full Sample and Subsamples

\begin{tabular}{|c|c|c|c|c|c|c|c|c|c|c|c|c|c|c|}
\hline \multirow[b]{2}{*}{ year } & \multicolumn{2}{|c|}{ Full Sample } & \multicolumn{2}{|c|}{ Male Sample } & \multicolumn{2}{|c|}{ Trucker Sample } & \multicolumn{2}{|c|}{$\begin{array}{l}\text { Trucker Union } \\
\text { Subsample }\end{array}$} & \multicolumn{2}{|c|}{$\begin{array}{l}\text { Trucker Non-Union } \\
\text { Subsample }\end{array}$} & \multicolumn{2}{|c|}{$\begin{array}{l}\text { For Hire Trucking } \\
\text { Sector }\end{array}$} & \multicolumn{2}{|c|}{$\begin{array}{l}\text { Private Carriage } \\
\text { Trucking Sector }\end{array}$} \\
\hline & 1983 & 2009 & 1983 & 2009 & 1983 & 2009 & 1983 & 2009 & 1983 & 2009 & 1983 & 2009 & 1983 & 2009 \\
\hline Obs. & 122,045 & 1874 & 65,126 & 47,792 & 2634 & 1874 & 878 & 280 & 1756 & 1594 & 816 & 569 & 1818 & 1305 \\
\hline Real Wage & 1220.45 & 13.28 & 13.38 & 13.54 & 12.40 & 12.32 & 11.99 & 12.18 & 10.78 & 10.52 & 10.49 & 10.64 & 10.39 & 10.59 \\
\hline Experience & 15.02 & 21.94 & 15.17 & 18.87 & 16.98 & 21.94 & 20.37 & 24.61 & 15.20 & 21.46 & 19.49 & 24.42 & 15.74 & 20.62 \\
\hline High School & 0.38 & 0.54 & 0.36 & 0.28 & 0.52 & 0.54 & 0.56 & 0.55 & 0.50 & 0.54 & 0.51 & 0.58 & 0.53 & 0.52 \\
\hline Some College & 0.10 & 0.27 & 0.09 & 0.27 & 0.06 & 0.27 & 0.06 & 0.28 & 0.07 & 0.26 & 0.07 & 0.24 & 0.06 & 0.28 \\
\hline College & 0.24 & 0.05 & 0.25 & 0.35 & 0.02 & 0.05 & 0.03 & 0.07 & 0.02 & 0.05 & 0.03 & 0.05 & 0.02 & 0.06 \\
\hline Male & 0.58 & 1.00 & 1.00 & 1.00 & 1.00 & 1.00 & 1.00 & 1.00 & 1.00 & 1.00 & 1.00 & 1.00 & 1.00 & 1.00 \\
\hline Union & 0.24 & 0.15 & 0.27 & 0.14 & 0.34 & 0.15 & 1.00 & 1.00 & 0.00 & 0.00 & 0.45 & 0.11 & 0.29 & 0.17 \\
\hline
\end{tabular}


Appendix B: OLS Regression: Wage Percentile as Dependent Variable

\begin{tabular}{|c|c|c|c|c|c|c|c|c|c|c|c|c|}
\hline \multirow{3}{*}{$\begin{array}{c} \\
\\
\text { Real Value of } \\
\text { Fed. Min. } \\
\text { Wage }\end{array}$} & \multicolumn{6}{|c|}{ Full Sample } & \multicolumn{6}{|c|}{ Truckers } \\
\hline & \multicolumn{2}{|l|}{ 90th } & \multicolumn{2}{|l|}{ 50th } & \multicolumn{2}{|l|}{ 10th } & \multicolumn{2}{|l|}{ 90th } & \multicolumn{2}{|l|}{ 50th } & \multicolumn{2}{|l|}{ 10th } \\
\hline & $\begin{array}{l}-0.016 \\
-(1.35)\end{array}$ & & $\begin{array}{r}0.006 \\
(0.58)\end{array}$ & & $\begin{array}{l}0.013 \\
(1.06)\end{array}$ & & $\begin{array}{l}-0.002 \\
-(0.18)\end{array}$ & & $\begin{array}{l}-0.032 \\
-(2.03)\end{array}$ & $* *$ & $\begin{array}{l}-0.019 \\
-(0.97)\end{array}$ & \\
\hline $\begin{array}{l}\text { Union } \\
\text { Coverage }\end{array}$ & $\begin{array}{l}-0.003 \\
-(0.42)\end{array}$ & & $\begin{array}{l}-0.003 \\
-(0.48)\end{array}$ & & $\begin{array}{l}0.003 \\
(0.33)\end{array}$ & & $\begin{array}{l}0.024 \\
(3.80)\end{array}$ & $* * *$ & $\begin{array}{l}0.046 \\
(5.60)\end{array}$ & $* * *$ & $\begin{array}{l}0.041 \\
(5.82)\end{array}$ & $* * *$ \\
\hline Year & $\begin{array}{l}0.014 \\
(5.05)\end{array}$ & $* * *$ & $\begin{array}{l}0.009 \\
(3.96)\end{array}$ & $* * *$ & $\begin{array}{l}0.007 \\
(2.31)\end{array}$ & $* *$ & $\begin{array}{l}0.015 \\
(5.02)\end{array}$ & $* * *$ & $\begin{array}{l}0.028 \\
(7.44)\end{array}$ & $* * *$ & $\begin{array}{l}0.028 \\
(6.12)\end{array}$ & $* * *$ \\
\hline Year $>=1992$ & $\begin{array}{r}-0.000005 \\
-(0.35)\end{array}$ & & $\begin{array}{r}-0.00002 \\
-(2.92)\end{array}$ & $* * *$ & $\begin{array}{r}-0.00001 \\
-(0.89)\end{array}$ & & $\begin{array}{r}-0.00001 \\
-(0.82)\end{array}$ & & $\begin{array}{r}-0.00001 \\
-(0.63)\end{array}$ & & $\begin{array}{r}-0.000004 \\
-(0.22)\end{array}$ & \\
\hline $\begin{array}{l}\text { Coeff. Var. } \\
\text { Edu }\end{array}$ & $\begin{array}{l}-1.863 \\
-(1.67)\end{array}$ & $*$ & $\begin{array}{l}-0.751 \\
-(0.92)\end{array}$ & & $\begin{array}{l}0.100 \\
(0.09)\end{array}$ & & $\begin{array}{l}-1.549 \\
-(1.72)\end{array}$ & $*$ & $\begin{array}{l}-1.465 \\
-(1.16)\end{array}$ & & $\begin{array}{l}-1.655 \\
-(0.99)\end{array}$ & \\
\hline $\begin{array}{l}\text { Coeff. Var. } \\
\text { Exp }\end{array}$ & $\begin{array}{l}-0.180 \\
-(2.06)\end{array}$ & $* *$ & $\begin{array}{l}-0.333 \\
-(4.87)\end{array}$ & $* * *$ & $\begin{array}{l}-0.637 \\
-(7.42)\end{array}$ & $* * *$ & $\begin{array}{l}-0.061 \\
-(3.97)\end{array}$ & $* * *$ & $\begin{array}{l}-0.089 \\
-(4.05)\end{array}$ & $* * *$ & $\begin{array}{l}-0.095 \\
-(3.98)\end{array}$ & $* * *$ \\
\hline $\begin{array}{c}\text { P-value of } \\
\text { Joint } \\
\text { Hypothesis I }\end{array}$ & 0.016 & $* *$ & 0.000 & $* * *$ & 0.000 & $* * *$ & 0.002 & $* * *$ & 0.002 & $* * *$ & 0.001 & $* * *$ \\
\hline $\begin{array}{c}\text { P-value of } \\
\text { Joint } \\
\text { Hypothesis II }\end{array}$ & 0.319 & & 0.824 & & 0.303 & & 0.000 & $* * *$ & 0.000 & $* * *$ & 0.000 & $* * *$ \\
\hline R-Squared & 0.980 & & 0.939 & & 0.906 & & 0.786 & & 0.842 & & 0.809 & \\
\hline
\end{tabular}

